\title{
Protective Effect of Beta Glucan on Pulmonary Aspergillosis Model in Neutropenic Rats
}

\author{
Beta-Glukanın Nötropenik Sıçanlardaki \\ Pulmoner Aspergilloz Modeli Üzerindeki \\ Koruyucu Etkisi
}

Kenan HIZEL, MD, ${ }^{a}$
Ayşe KALKANCI, MD, ${ }^{b}$
Kayhan ÇAĞLAR, MD, ${ }^{b}$
Sibel AYDOĞAN, MD, ${ }^{c}$
Murat DiZBAY, MD,
Işıl FiDAN, MD, ${ }^{b}$
Aylar POYRAZ, MD, ${ }^{d}$
Semra KUŞTiMUR, MD ${ }^{b}$

Departments of

alnfectious Diseases and

Clinical Microbiology,

'Microbiology,

dPathology,

Gazi University Faculty of Medicine,

'Department of Microbiology and

Clinical Microbiology,

Hacettepe University Faculty of Medicine, Ankara

Geliş Tarihi/Received: 17.02 .2010

Kabul Tarihi/Accepted: 04.08.2010

This study was presented as a poster in $3^{\text {rd }}$ Trends in Medical Mycology congress, 28-31 Oct 2007 Turin, ITALY.

Yazıșma Adresi/Correspondence: Kenan HIZEL, MD

Department of Infectious Diseases and Clinical Microbiology,

Gazi University Faculty of Medicine, Ankara,

TÜRKIYE/TURKEY

khizel@gazi.edu.tr

\begin{abstract}
Objective: Pulmonary aspergillosis is a serious opportunistic infection which might be fatal in immunocompromised patients. Immunity against aspergillosis requires the coordinated action of components of the innate and adaptive immune systems. Beta-glucan is one of the immunomodulatory agents which got much attention in recent years. It was used as a preventive agent for the development of infections. However, information about its the possible protective effect on fungal infections are limited. The aim of this study aimed to investigate the possible protective effects of beta-glucan against Aspergillus fumigatus infection. Material and Methods: We evaluated oral beta glucan administration for its ability to enhance resistance of the rats to experimentally induced pulmonary aspergillosis. Fifty-eight rats were divided into three groups: Thirty five rats were immunosuppressed and infected with Aspergillus fumigatus (infected group); 15 were immunosuppressed, infected and treated with oral beta-glucan (beta-glucan group); and eight were healthy controls. Rats were sacrificed on the tenth day of the experiment and tissue specimens were cultured. Chitin, galactomannan antigen and glucan levels were detected. Results: Beta-glucan enhanced the resistance against Aspergillus infection. The survival rates were $62.9 \%$ and $93.4 \%$ in the infected and beta-glucan groups, respectively $(\mathrm{p}<0.05)$. Beta glucan also limited the fungal burden. Conclusion: Our results suggested that Aspergillus invasion did not develop in beta-glucan group in spite of the occurence of fungal colonization in neutropenic rats. Beta-glucan was able to improve the resistance against $A$. fumigatus infection.
\end{abstract}

Key Words: Aspergillosis; beta-glucans; cytoprotection; immunosuppression

ÖZET Amaç: Pulmoner aspergilloz immün yetmezlikli hastalarda ölümcül olabilen ciddi bir firsatçı enfeksiyondur. Asperjillozise karşı bağışıklık doğuştan gelen ve adaptif immün sistemlerin bileşenlerinin birlikte hareket etmesini gerektirir. Beta-glukan son yıllarda çok dikkat çeken immünomodülatör ajanlardan biridir. Enfeksiyon gelişiminde koruyucu ajan olarak kullanılmıştır. Fakat mantar enfeksiyonlarındaki olası koruyucu etkisi hakkındaki bilgi sınırlıdır. Bu çalışmanın amacı beta-glukanın Aspergillus fumigatus enfeksiyonuna karşı olası koruyucu etkilerini araştırmaktı. Gereç ve Yöntemler: Oral beta-glukan verilmesinin farelerin deneysel olarak oluşturulmuş pulmoner aspergilloza karşı direncini artırma yeteneğini değerlendirdik. Toplam 58 sıçan üç gruba ayrıldı: Otuzbeş sıçanın bağışıklığı baskılandı ve Aspergillus fumigatus ile enfekte edildi (enfekte grup); 15'inin bağışıklığı baskılanmıştı, enfekteydi ve oral beta-glukan ile tedavi edildi (beta-glukan grup); sekizi ise sağlıklı kontroldu. Sıçanlar deneyin onuncu gününde kesildi ve doku örnekleri kültüre edildi. Kitin, galaktomannan antijeni ve glukan düzeyleri saptandı. Bulgular: Beta-glukan Asperjillus enfeksiyonuna karşı direnci artırdı. Sağkalım oranları enfekte grupta ve beta-glukan grubunda sırasıyla \%62.9 ve \%93.4 idi ( $\mathrm{p}<0.05$ ). Beta-glukan aynı zamanda mantar yükünü sınırladı. Sonuç: Bulgularımız nötropenik sıçanlarda mantar kolonizasyonu oluşmasına rağmen beta-glukan grubunda Aspergillus invazyonunun gelişmediğini ortaya koydu. Beta-glukan $A$. fumigatus enfeksiyonuna karşı direnci artırabildi.

Anahtar Kelimeler: Asperjilozis; beta-glukanlar; hücre koruma; immünosupresyon 


\section{A} spergillus species are widely distributed in nature and survive well in the environinfection. Pulmonary aspergillosis is a serious opportunistic infection which might be fatal in immunocompromised patients. Host defects such as neutropenia, defective neutrophil function, corticosteroid therapy, use of immunosuppressive agents and late-stage of human immunodeficiency virus infection cause a predisposition to invasive aspergillosis. Factors that aid the fungus in the initial stages are not known, but the ability of proteins on the surface of conidia to bind fibrinogen and laminin probably contributes to adherence. First host defence mechanisms against Aspergillus conidia are macrophages which phagocytose and kill them by nonoxidative mechanisms. Neutrophils inhibit survived conidia via generating an oxidative burst and secreting reactive oxygen intermediates. Immunity against aspergillosis requires the coordinated action of components of the innate and adaptive immune systems. Although little is known about adaptive immunity in humans, it was shown that Th1 lymphocyte reactivity was associated with resistance whereas secretion of Th2 cytokines was correlated with the development of invasive disease. ${ }^{1-4}$

Immunomodulatory agents may be clinically significant in immunocompromised patients. ${ }^{5,6} \mathrm{Be}-$ ta-glucan is one of these agents which got much attention in recent years. It constitutes 65 to $90 \%$ of the structural polysaccharide of the fungal cell wall. Beta-glucan is not biosynthesized by mammals, however it modulates a number of immune activities in humans. ${ }^{7-9}$ Several studies conducted in the past decade showed that beta-glucan inhibited tumor development, activated macrophages, induced production of cytokines, increased hematopoiesis, exerted radioprotective effects, improved wound healing by inducing the macrophages' release of wound growth factors, increased salivary IgA concentration, and enhanced defence against infections. ${ }^{10-14}$ Previous researches indicated that beta glucan was used as a preventive agent in the treatment of bacterial infections. ${ }^{15-17}$ Studies, however, about the possible protective effect on fungal infections are limited. ${ }^{18-20}$
We designed this study to investigate the possible protective effects of beta-glucan against $A s^{-}$ pergillus fumigatus infection using conventional and serological approaches in an immunosuppressed rat model.

\section{MATERIAL AND METHODS}

\section{ANIMALS}

Fifty-eight female Wistar albino rats, weighing initially $200 \pm 0.15 \mathrm{~g}$ and 4 weeks of age, were obtained from Gazi University School of Medicine Experimental Animal Research Center. They were housed 4-5 per cage in a room with a 12/12-hour light/dark cycle and ambient temperature of 20 to $25^{\circ} \mathrm{C}$. The rats had free access to food and water. The animal experiments were conducted according to the 'Guide for the Care and Use of Laboratory Animals' of the Ethical Committee of Gazi University School of Medicine. Effort was made to minimize animal suffering and to reduce the number of animals used.

\section{STUDY GROUPS}

The rats were divided into three groups:

1) Healthy control group $(n=8)$ : No immunosuppression or infection; not received beta-glucan.

2) Infected group ( $n=35)$ : Ten mg of 5-fluorouracil was used for immunosuppression of the rats. Following the development of neutropenia, the rats were infected with Aspergillus conidia by the inhalation model on fifth day and monitored until tenth day of the experiment. ${ }^{20}$ For the inhalation model, a total of $10 \mathrm{ml}$ of the $10^{8}$ conidia per $\mathrm{ml}$ suspension was inhalated in a nebulizer for 10 minutes.

3) Beta-glucan group ( $n=15)$ : Ten mg of 5-fluorouracil was used for immunosuppression of the rats. On the third day, daily $35 \mathrm{mg}$ oral beta-1-3-Dglucan derived from Saccharomyces cerevisiae (Immunex $^{\circledR}$ ) was started for each rat intragastrically. Similar to the infected group, the rats were infected with Aspergillus conidia by the inhalation model within five days, and monitored until tenth day.

Granulocyte counts in blood samples were obtained using a hemacytometer to determine whet- 
her the animals were immunosuppressed. The rats were accepted as immunosuppressed if their neutrophil counts were below 500 . To prevent bacterial superinfection, animals were given teicoplanin intramuscularly and ciprofloxacin was added to their drinking water throughout the experiment. On the tenth day of the experiment, the rats in each group were sacrified by exsanguination under general anesthesia, achieved by intramuscular ketamine $(100 \mathrm{mg} / \mathrm{kg})$. Blood, bronchoalveolar lavage and lung samples were collected and then stored at $-80^{\circ} \mathrm{C}$ until assessment of fungal burden.

\section{DETERMINATION OF A. FUMIGATUS IN LUNG TISSUE}

Both lungs were removed aseptically and homogenized in $10 \mathrm{ml}$ of sterile saline with a tissue homogenizer (Dremel, Racine, Wis.). Fifty microliters of each lung homogenate was placed on Sabouraud's dextrose agar and incubated for one week at $24^{\circ} \mathrm{C}$.

\section{HISTOLOGY}

Tissue specimens were fixed in 10\% formol-saline and stained with Gomori methenamine silver stain for microscopic examination.

\section{CHITIN DETERMINATION IN LUNGS}

Chitin levels were measured as described before. ${ }^{22,23}$ Lung homogenates were centrifuged. The pellets were resuspended in sodium lauryl sulfate $(3 \%$ [wt $/ \mathrm{vol}])$ and heated at $100^{\circ} \mathrm{C}$ for $15 \mathrm{~min}$. After centrifugation, pellets were washed with distilled water, resuspended in $\mathrm{KOH}(120 \%$ [wt/vol]), and then heated at $130^{\circ} \mathrm{C}$ for $60 \mathrm{~min}$. After cooling, ice-cold ethanol (75\%[vol/vol]) was added. Tubes were kept on ice for $15 \mathrm{~min}$ and Celite545 was added. After centrifugation, pellets were washed and suspended in a solution containing $\mathrm{NaNO}_{2}$ (5\% [wt/vol]) and $\mathrm{KHSO}_{4}(5 \%$ [wt/vol]). Samples were mixed gently for $15 \mathrm{~min}$ and then centrifuged. The supernatant was mixed with ammonium sulfate (12.5\% [wt/vol]) and 3-methyl-2-thiazolone hydrazone $\mathrm{HCl}$ monohydrate. The mixture was heated at $100^{\circ} \mathrm{C}$ for $3 \mathrm{~min}$. After cooling, $\mathrm{FeCl}_{3} \cdot 6 \mathrm{H}_{2} \mathrm{O}$ $(0.83 \%[\mathrm{wt} / \mathrm{vol}])$ was added to the mixture, and the optical density at $650 \mathrm{~nm}$ was measured after 25 min. Glucosamine $(10 \mathrm{~g} / \mathrm{ml})$ was used as a standard.
The chitin level was expressed as an arbitrary unit (g) based on the glucosamine equivalent.

\section{DETECTION OF THE GALACTOMANNAN ANTIGEN OF A. FUMIGATUS}

Galactomannan detection was performed using a commercially available ELISA kit (Platelia Aspergillus, BioRad, France) according to the manufacturer's instructions. Samples with a positivity index of 0.7 were considered positive according to the consensus report mentioned in the literature. ${ }^{24}$

\section{GLUCAN ASSAY}

The glucan assay was performed according to the protocol supplied by the manufacturer (Fungitell, CAPE COD, USA). We measured glucan levels in the sera of the animals after 24 hours of the last administration of oral beta glucan. Samples which had glucan values over $80 \mathrm{pg} / \mathrm{ml}$ was considered as positive, values between 60 and $79 \mathrm{pg} / \mathrm{mL}$ were considered equivocal and values below $60 \mathrm{pg} / \mathrm{ml}$ considered as negative. ${ }^{25}$

\section{STATISTICAL ANALYSIS}

All statistical analyses were performed using SPSS. v10 programme. The valuability of the diagnostic methods in the diagnosis of invasive aspergillosis were analyzed using chi-square and Yates corrected chi-square tests. Mc Nemar test and Mann Whitney U were used for the comparison of infected and beta-glucan groups. A survival plot was drawn by Kaplan-Meier analysis. $\mathrm{P}$ value $<0.05$ was considered as statistically significant.

\section{RESULTS}

All rats that received 5-fluorouracil were immunosuppressed. Invasive aspergillosis was confirmed by the presence of fungal hyphae and the growth of Aspergillus colonies in the lung tissue samples of the rats. By these methods, fungal invasion was demonstrated in the infected group, but not in the healthy control and beta glucan groups. The other infection parameters such as glucan, galactomannan, chitin were also studied to evaluate the therapeutic effect of beta-glucan. Our results are summarized below: 


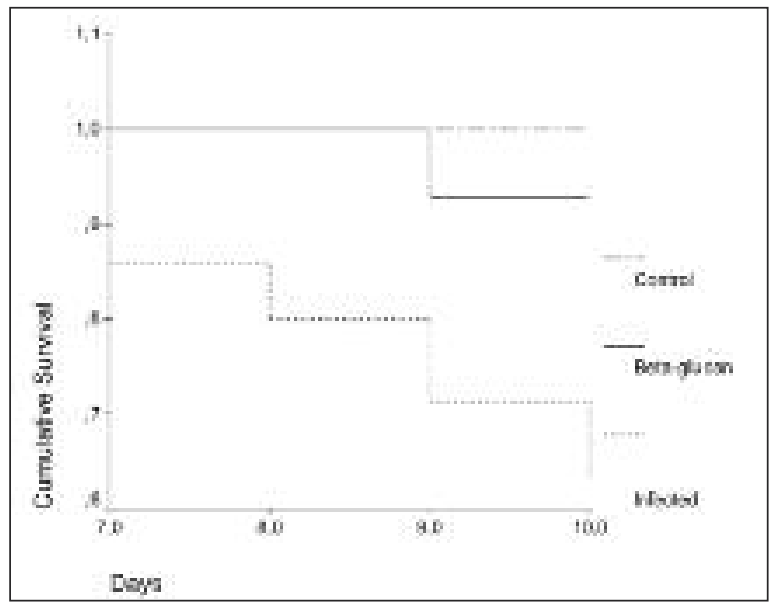

FIGURE 1: Survival of the rats during the study period. First rat death was observed on the seventh day. Rats in the beta-glucan group survived longer than the rats in the infected group $(p<0.05)$

Beta-glucan enhanced the resistance against Aspergillus infection: The survival rates were determined for each group (Figure 1). Twenty two of $35(62.9 \%)$ rats in the infected group, and 14 of 15 (93.4\%) rats in the beta-glucan group had survived until tenth day of the study ( $\mathrm{p}<0.05,95 \%$ CI, 9.7910.06).

Beta-glucan limited the fungal burden in the lungs: Fungal cultures yielded $A$. fumigatus colonies in $100 \%$ of the lung samples in 22 rats survived in the infected group, and in none of the lung samples in the beta-glucan group ( $\mathrm{p}<0.05)$. Mean chitin levels were $58.52 \pm 10.52$, and $29.46 \pm 10.06 \mathrm{~g}$ glucosamine in the infected, and beta-glucan groups, respectively $(\mathrm{p}<0.001)$.

Beta-glucan reduced the positivity rates of glucan and galactomannan of Aspergillus: Aspergillus galactomannan antigen positivity was found higher in the serum samples of the infected group when compared to those of the beta-glucan group (Table 1$)(\mathrm{p}<0.01)$. We could not determine galac- tomannan antigen activity in the bronchoalveolar lavage specimens because of insufficient material. Glucan positivity was determined in 15 of 22 $(68.1 \%)$ rats in infected group, while only in three of $14(21.4 \%)$ rats in beta-glucan group $(\mathrm{p}<0.05)$ had positivity. Glucan and galactomannan activities were not detected in healthy controls.

\section{DISCUSSION}

Mortality due to invasive aspergillosis is still high in immunocompromised patients despite appropriate antimicrobial therapy. These hosts exhibit a complex change in immunity characterized by deactivation of macrophages and an altered cellular immune response. Thus, modulation of immunosuppression has to be taken into account for the treatment in addition to preventive measures such as chemoprophylaxis and reducing environmental exposure. It was reported that immunomodulators like GM-CSF, IFN-gamma and TNF-alpha enhanced the host defence against pulmonary aspergillosis in some studies. ${ }^{26-28}$

Beta-glucan is known to exert immunomodulatory effects when administered to animals and humans. Our study was conducted to demonstrate the possible protective effect of beta-glucan against lung aspergillosis in the neutropenic rat model. Beta-glucan was observed to prevent invasive pulmonary aspergillosis. We found that the survival rate of the rats in the beta-glucan group was higher than that in the infected group $(93.4 \%$ vs $62.9 \%$ respectively, $\mathrm{p}<0.01$ ). We did not determine the survival benefit of beta-glucan after a period of five days followed by a period when beta glucan was not administered. Although it could be regarded as a limitation, the main goal of our study was to evaluate the beneficial effects of beta glucan on fungal

\begin{tabular}{|lccc|}
\hline \multicolumn{4}{|c|}{ TABLE 1: Results in groups. } \\
\hline Method & \multicolumn{1}{c|}{ Number of positive patients (\%) } & p value \\
& Infected group & Beta-glucan group & $<0.01$ \\
Histopathology of lung tissue & $22 / 22(100 \%)$ & 0 & $<0.01$ \\
Culture of lung tissue & $22 / 22(100 \%)$ & 0 & $<0.01$ \\
Galactomannan (Sera) & $7 / 22(31.8 \%)$ & $1 / 14(7 \%)$ & $<0.05$ \\
Glucan (Sera) & $15 / 22(68.1 \%)$ & $3 / 14(21.4 \%)$ & \\
\hline
\end{tabular}


burden, we did not aim to evaluate the effect of beta glucan on survival. Since survival rate cannot be used as a reliable parameter solely, other therapeutic endpoints, such as histopathology, culture of the samples, detection of fungal antigens and chitin activity were also performed. These tests were also demonstrated the protective effect of beta-glucan in pulmonary aspergillosis.

Several in vivo studies demonstrated that betaglucan enhanced resistance against various infections. ${ }^{8-20}$ Pelizon et al. reported that beta-glucan administration enhanced fungicidal activity on $\mathrm{Pa}$ racoccidioides brasiliensis in the mice model by priming spleen cells for high production of IL-12 and TNF-alpha as well as increasing NK cell activity. ${ }^{19}$ In a rat model of sepsis, the protective effect of beta-glucan against oxidative organ injury by depressing lipid peroxidation was demonstrated. ${ }^{29} \mathrm{Si}-$ milar effects were also reported in burn-induced oxidative organ damage in rats. ${ }^{30} \mathrm{In}$ a study by Li et al., beta-glucan was found to augment protective immunity against Listeria monocytogenes in mice. They found that Acetobacter-derived soluble branched $(1,4)$-beta-D-glucan enhanced antibacterial activity via inceasing IL-12 levels through Tolllike receptor 4, and augmenting Th1/Tc1 responses. ${ }^{31}$ In two double-blind placebo-controlled randomised phase II trials by Babineau et al., the protective effect of beta- $\mathrm{D}$ glucans against postoperative infections was also observed in high risk surgical patients. ${ }^{32,33}$ They indicated that patients who received poly-(1-6)-beta-D-glucopyranosyl(1-3)-beta-D glucopyranose glucan had significantly fewer infectious complications, decreased intravenous antibiotic requirement and shorter intensive care unit length of stay. All of these studies showed that beta-glucan nonspecifically modulated immune responses by various mechanisms such as activating leukocyte functions and enhancing cytokine secretions.

Histopathological examination is the gold standard method in the diagnosis of invasive aspergillosis since it demonstrates hyphal elements in tissues. $^{34,35}$ In our study, histopathological examination revealed an invasion to the lung tissues in the infected group, but not in the beta-glucan and control groups. Similarly, we obtained positive culture results in all of the rats in the infected group. Since the samples were taken under surgical conditions by direct macroscopic observation, the percentage of positive culture results were high in experimental animals. Histopathological study, however, could not be easily performed and culturing usually gives negative results in human subjects. Moreover, invasive aspergillosis is not sufficiently diagnosed only by culturing which cannot distinguish colonization from infection. ${ }^{34}$

Galactomannan and glucan assays are usually regarded as sensitive tests in the diagnosis of invasive aspergillosis. ${ }^{24,36-38} \mathrm{We}$ found that galactomannan levels were lower in the serum samples of the beta-glucan group than those in the infected group. We also found that glucan levels were lower in the beta-glucan group. We suppose that the low positivity $(21.4 \%)$ is due to the protective effect of the beta-glucan against aspergillosis in beta-glucan group. Since orally administered beta-glucan was rapidly cleared from the blood circulation, ${ }^{39}$ and we measured glucan levels after 24 hours of the last dose, glucan levels that we measured in our study could be accepted as an indicator of infection. We also found low chitin levels in beta- glucan group when compared to the infected group. Our results revealed that oral beta-glucan treatment depressed the levels of the fungal antigens which were the indicators of fungal burden.

In conclusion, our results indicated that $A s^{-}$ pergillus invasion did not develop in beta-glucan group in spite of the occurence of fungal colonization in neutropenic rats. This might be due to the protective effect of oral administration of beta-glucan. Additionally, our results suggested that betaglucan derived from S.cerevisiae was able to improve immune functions which contributed to A.fumigatus elimination. These observations need to be supported with well-planned clinical studies in humans.

\section{Acknowledgements}

This study was conducted with the financial support of Gazi University Scientific Research Council, project number: 01/2005-37. 


\section{REFERENCES}

1. Hebart $H$, Bollinger $C$, Fisch $P$, Sarfati J, Meisner $C$, Baur M, et al. Analysis of T-cell responses to Aspergillus fumigatus antigens in healthy individuals and patients with hematologic malignancies. Blood 2002;100(13):45218.

2. Botterel F, Gross K, Ibrahim-Granet O, Khoufache K, Escabasse V, Coste A, et al. Phagocytosis of Aspergillus fumigatus conidia by primary nasal epithelial cells in vitro. BMC Microbiol 2008;8:97.

3. Askew DS. Aspergillus fumigatus: virulence genes in a street-smart mold. Curr Opin Microbiol 2008;11(14):331-7.

4. Gallin Jl, Zarember K. Lessons about the pathogenesis and management of aspergillosis from studies in chronic granulomatous disease. Trans Am Clin Climatol Assoc 2007:118:175-85.

5. Krishnan-Natesan S, Chandrasekar PH. Current and future therapeutic options in the management of invasive aspergillosis. Drugs 2008;68(3):265-82.

6. Casadevall A, Pirofski LA. Adjunctive immune therapy for fungal infections. Clin Infect Dis 2001;33(7):1048-56.

7. Latge JP. The cell wall: a carbohydrate armour for the fungal cell. Mol Microbiol 2007; 66(2):279-90.

8. Estrada A, Yun CH, Van Kessel A, Li B, Hauta $S$, Laarveld B. Immunomodulatory activities of oat beta-glucan in vitro and in vivo. Microbiol Immunol 1997;41(12):991-8.

9. Lull C, Wichers HJ, Savelkoul HF. Antiinflammatory and immunomodulating properties of fungal metabolites. Mediators Inflamm 2005;2005(2):63-80.

10. Akramiene D, Kondrotas A, Didziapetriene J, Kevelaitis E. Effects of beta-glucans on the immune system. Medicina (Kaunas) 2007;43(8):597-606.

11. Yoon TJ, Kim TJ, Lee H, Shin KS, Yun YP, Moon WK, et al. Anti-tumor metastatic activity of beta-glucan purified from mutated Saccharomyces cerevisiae. Int Immunopharmacol 2008;8(1):36-42.

12. Ishibashi K, Miura NN, Adachi Y, Ogura N, Tamura H, Tanaka S, et al. Relationship between the physical properties of Candida albicans cell well beta-glucan and activation of leukocytes in vitro. Int Immunopharmacol 2002;2(8):1109-22.

13. Kataoka K, Muta T, Yamazaki S, Takeshige K. Activation of macrophages by linear $(1,3)$ beta-D-glucans. Impliations for the recognition of fungi by innate immunity. $\mathrm{J}$ Biol Chem 2002;277(39):36825-31.

14. Lehne $G$, Haneberg $B$, Gaustad $P$, Johansen PW, Preus H, Abrahamsen TG. Oral adminis- tration of a new soluble branched beta-1,3-Dglucan is well tolerated and can lead to increased salivary concentrations of immunoglobulin $A$ in healthy volunteers. Clin Exp Immunol 2006;143(1):65-9.

15. Hetland G, Sandven P. Beta-1,3-glukan reduces of Mycobacterium tuberculosis in macrophage cultures. FEMS Immunol Med Microbiol 2002;33(1): 41-5.

16. Williams DL, Di Luzio NR. Glucan induced modification of experimental Staphylococcus aureus infection in normal, leukemic and immunosuppressed mice. Adv Exp Med Biol 1979;121(A):291-306.

17. Kournikakis B, Mandeville R, Brousseau $P$, Ostroff $G$. Anthrax-protective effets of yeast beta-1,3 glucans. MedGenMed 2003;5(1):1.

18. Meira DA, Pereira PC, Marcondes-Machado J, Mendes RP, Barraviera B, Pellegrino Júnior $\mathrm{J}$, et al. The use of glucan as immunostimulant in the treatment of paracoccidiomycosis. Am J Trop Med Hyg 1996;55(5):496-503.

19. Pelizon AC, Kaneno R, Soares AM, Meira DA, Sartori A. Immunomodulatory activities associated with beta-glucan derived from Saccharomyces cerevisiae. Physiol Res 2005; 54(5):557-64.

20. Browder IW, Williams DL, Kitahama A, Di Luzio NR. Modification of post-operative C. albicans sepsis by glucan immunostimulation. Int J Immunopharmacol 1984;6(1):19-26.

21. Gavaldà J, Martín MT, López P, Gomis X, Ramírez JL, Rodríguez D, et al. Efficacy of nebulized liposomal amphotericin B in treatment of experimental pulmonary aspergillosis. Antimicrob Agents Chemother 2005;49(7):3028-30.

22. Hayashi $R$, Kitamoto $N$, lizawa $Y$, Ichikawa $T$, Itoh K, Kitazaki T, et al. Efficacy of TAK-457, a novel intravenous triazole, against invasive pulmonary aspergillosis in neutropenic mice. Antimicrob Agents Chemother 2002;46(2):283-7.

23. Lehmann PF, White LO. Chitin assay used to demonstrate renal localization and cortisoneenhanced growth of Aspergillus fumigatus mycelium in mice. Infect Immun 1975;12(5):987-92.

24. Herbrecht R, Letscher-Bru V, Oprea C, Lioure B, Waller J, Campos F, et al. Aspergillus galactomannan detection in the diagnosis of invasive aspergillosis in cancer patients. $\mathrm{J}$ Clin Oncology 2002;20(7):1898-906

25. Odabasi Z, Mattiuzzi G, Estey E, Kantarjian H, Saeki F, Ridge R, et al. $\beta$-D-glucan as a diagnostic adjunct for invasive fungal infections: Validation, cutoff development, and performance in patients with acute myelogenous leukemia and myelodysplastic syndrome. Clin Infect Dis 2004;39(2):199-205.
26. Schelenz S, Smith DA, Bancroft GJ. Cytokine and chemokine responses following pulmonary challenge with Aspergillus fumigatus: obligatory role of TNF-alpha and GM-CSF in neutrophil recruitment. Med Mycol 1999;37(3):183-94.

27. Roilides E, Dimitriadou-Georgiadou A, Sein T, Kadiltsoglou I, Walsh TJ. Tumor necrosis factor alpha enhances antifungal activities of polymorphonuclear and mononuclear phagocytes against Aspergillus fumigatus. Infect Immun 1998;66(12):5999-6003.

28. Mehrad B, Strieter RM, Standiford TJ. Role of TNF-a in pulmonary host defense in murine invasive aspergillosis. J Immunol 1999;162(3):1633-40.

29. Sener G, Toklu H, Ercan F, Erkanli G. Protective effect of beta-glucan against oxidative organ injury in a rat model of sepsis. Int Immunopharmacol 2005;5(9):1387-96.

30. Toklu HZ, Sener G, Jahovic N, Uslu B, Arbak $S$, Yeğen BC. Beta-glucan protects against burn-induced oxidative organ damage in rats. Int Immunopharmacol 2006;6(2):156-69.

31. Li W, Yajima T, Saito K, Nishimura H, Fushimi $\mathrm{T}$, Ohshima Y, et al. Immunostimulating properties of intragastrically administered Acetobacter-derived soluble branched $(1,4)$-beta-D-glucans decrease murinesusceptibility to Listeria monocytogenes. Infect Immun 2004;72(12):7005-11.

32. Babineau TJ, Marcello P, Swails W, Kenler A, Bistrian B, Forse RA. Randomized phase I/II trial of a macrophage-specific immunomodulator (PGG-glucan) in high-risk surgical patients. Ann Surg 1994;220(5):601-9.

33. Babineau TJ, Hackford A, Kenler A, Bistrian B, Forse RA, Fairchild PG, et al. A phase II multicenter, double-blind, randomized, placebo-controlled study of three dosages of an immunomodulator (PGG-glucan) in highrisk surgical patients. Arch Surg 1994;129(11): 1204-10.

34. Richardson MD. Changing patterns and trends in systemic fungal infections. J Antimicrob Chemother 2005;56(Suppl 1):i5-i11.

35. Ascioglu S, Rex JH, de Pauw B, Bennett JE, Bille J, Crokaert F, et al. Defining opportunistic invasive fungal infections in immunocompromised patients with cancer and hematopoietic stem cell transplants: an international consensus. Clin Infect Dis 2002;34 (1):7-14.

36. Maertens J, Verhaegen J, Lagrou K, Van Eldere J, Boogaerts M. Screening for circulating galactomannan as a noninvasive diagnostic tool for invasive aspergillosis in prolonged neutropenic patients and stem cell transplantation recipients: a prospective validation. Blood 2001;97(6):1604-10. 
37. Maertens J, Van Eldere J, Verhaegen J, Verbeken E, Verschakelen J, Boogaerts M. Use of circulating galactomannan screening for early diagnosis of invasive aspergillosis in allogeneic stem cell transplant recipients. J Infect Dis 2002;186(9):1297-306.
38. Persat $F$, Ranque $S$, Derouin $F$, MichelNguyen A, Picot S, Sulahian A. Contribution of the $(1,3)$-beta-D-glucan assay for diagnosis of invasive fungal infections. J Clin Microbiol 2008;46(3):1009-13.
39. Yoshida M, Roth RI, Grunfeld C, Feingold KR, Levin J. Pharmacokinetics, biological effects, and distribution of (1-3) - $\cdots$-D-glucan in blood and organs in rabbits. Mediators Inflamm 1997;6(4):279-83. 